DOI: $10.1515 /$ abcsj-2016-0007

\title{
In Pursuit of Happiness: Escape, Change, and Return in Contemporary Academic Novels, Or Why I Read Campus Novels, But Possibly Shouldn't
}

\author{
MARTA ŁYSIK \\ University of Wrocław
}

\begin{abstract}
In this personal essay, the author compares her academic experiences to those of characters in the campus novels she enjoys reading. The novels she discusses here share a thematic concern with happiness and all seem to indicate that professional fulfillment and academic status are not sufficient in order to achieve that state.
\end{abstract}

Keywords: happiness, academic novel, Rachel Kadish, Tolstoy Lied, Graeme Simsion, The Rosie Project, Elisabeth Brink, Save Your Own.

Long ago I decided to make a life in higher education. I imagined that it would provide a good and ethical way of living, a consistently interesting work life, and a modicum of happiness. I enjoyed teaching and have been doing it for twenty years now, since I was sixteen. One of my top five strengths according to the Gallup Strengths Center is that I am a learner and have to teach myself new things all the time. I enjoy the life of the mind and the mentoring aspect of being a teacher since it capitalizes on another strength of mine, namely connectedness. To me the profession has all the responsibility and status I want in life. I can still be safely introverted in between teaching, conferences, and meetings. The extroverted moments help me appreciate the introverted ones. I need the two alternatives to keep me on my toes all the time, since humdrum dulls my wits. None of the lucrative or 9-to-5 jobs appeals to me.

Most of my life, I have read academic novels to reinforce my decision to make an academic life for myself, but what did I discover? All 
sorts of things that qualified and dampened what I realize now were my own naïve expectations. Since I am an introvert, a learner, and a reader, I resort to books to find out about reality, but my findings are often disturbing, sometimes disillusioning, sometimes in jarring conflict with real life. Perhaps I have read too many academic novels. How come in the institution that promotes the life of the mind, petty concerns are in the foreground? As I progressed in my academic life (I have worked in German, American, and Polish academe), I encountered many disillusioning facts. And reading academic fiction confirmed my discovery: that the academic life is more like other lives than I expected and hoped - it was going to be. That it consists of people, their issues, and insecurities, just like everywhere else I worked. That people can be gratuitously cruel. That there is no justice in human outcomes here, either. That the work is hard, sometimes repetitive, and occasionally not very interesting (the administrative tasks I am required to do suck out all of my creative juices). That academics are under stress a lot of the time, that they face frustration, that, in short, the outcome of taking a Ph.D. is not a guaranteed "happy ending."

I learned to find some satisfactions outside of academia. Yes, there are occasional moments of grace coming from interaction with colleagues and students, and thrills stemming from teaching and research, but I feel that to base one's sense of happiness on those fickle moments is not particularly wise. Reading helps, but perhaps one should limit the number of academic novels since - unfortunately - so few of them help me affirm the value of an academic career or promise me the happiness for which I chose it.

What is the valid reason for becoming an academic, I wonder? Certain talents and interests? And is there a space for happiness in that line of work? A job description could briefly state: teaching, research, and administration. How paper-pushing could ever be a source of joy is a mystery to me, but the remaining two could potentially provide a healthy mixture of sociability and solitude. What answer does literature have to offer to this question, i.e. does academic life make people happy? Or perhaps you already have to be happy when you enter academe? Of all the campus and academic novels I have read, not many were of an optimistic 
disposition, or depicted a happy academic life. What is wrong? Is it because life in general is tough regardless of one's career, or is it the university setting and its protagonists that guarantee misery until retirement? I do not think that the academic setting is to blame.

A glance at textbooks and articles concerning academic and campus novels proves that the word "happiness" does not appear. Even the humor in many novels, often under the guise of irony, satire, and sarcasm, can be rather crude. Merritt Moseley notes that

Discussions of the academic novel are, by and large, too humorless. Most academic novels are comic. This does not, or need not, make them satiric; and the non-satiric comic novel is not necessarily less worthy than the satiric novel or the so-called "serious" novel. (18)

Maybe happiness is too subjective a category to explain, or share; possibly laughter seems unacademic. Is humor a taboo when it comes to academia? No - there is academic humor - but I find that there is not enough of it in academic novels. Besides, humor is a subjective characteristic, defined and perceived differently by different people. Surely academic novels could be funnier, or as Moseley puts it:

While obviously there are some topics which do not lend themselves to comedy, there is no reason why higher education should be among them. Analysis of humor is of course nearly impossible and trying to persuade one person to laugh at what another finds funny is vain; but I take it as evident that humor adds to the pleasure of readers. I am convinced that the high incidence of comedy, ranging from the most delicate verbal touches to broad farce, in academic fiction is one of its most valuable and welcome traits. (19)

What if the humor in these novels was positive, not tinged with satirical edge, with hints of the negative? Would they be more satisfactory to me, in my own academic (mis)adventures? Would they serve me as a reminder of what is fine, amusing, and affirmative about the profession? Would I as an academic take myself less seriously, be less self-conscious, and therefore happier? Possibly.

The last resort, i.e. leaving the academy, can be liberating and can be the "happy ending" for some of the protagonists, in fiction and real life. 
Janice Rossen observes that several novels involve the most drastic measure: "many of the best university novels are about someone leaving academe at the end of the book" (188). I believe that individual happiness is contingent upon changing the status quo: changing oneself and/or the situation one is in, and sometimes it does entail leaving the academy. I have chosen three novels prioritizing happiness: Tolstoy Lied by Rachel Kadish, The Rosie Project by Graeme Simsion, and Save Your Own by Elisabeth Brink. Reading these academic novels has done me a world of good. The protagonists fixate on research first but realize it is not the path to happiness: one leaves, one stays but gets a life, and another one leaves, lives her life, and comes back to the academy. What, then, is the recipe for happiness, according to academic novels?

The eighth sentence of Tolstoy Lied: A Love Story by Rachel Kadish is a famous quote from Tolstoy, "Happy families are all alike; every unhappy family is unhappy in its own way," followed by a disillusioned comment by Tracy Farber, a 33-year-old Americanist and literary scholar:

Literary types swoon over that line, which opens Anna Karenina. But have they considered the philosophy they're embracing? If Tolstoy is to be taken at his word, a person must be unhappy in order to be interesting. If this is true, then certain other things follow. Happy people have no stories you might possibly want to hear. (Kadish 3 )

Professors of creative writing are famous for telling their students: "happiness writes white." Why is unhappiness a magnet when it comes to writers? Tracy bemoans "how hard it is to find a good nontragic American novel on academia's approved-reading list" (Kadish 4). This is another way of claiming that happiness cannot be interesting. To be happy is to be dull, almost mediocre:

In order to be happy, you must whitewash your personality; steamroll your curiosities, your irritations, your honesty and indignation. You must shed idiosyncratic dreams and march in lockstep with the hordes of the content. Happiness, according to this witticism of Tolstoy's, is not a plant with spikes and gnarled roots; it is a daisy in a field of a thousand daisies. It is for lovers of kitsch and those with subpar intelligence. (Kadish 3) 
I think that, contrary to what is believed, it is more of a challenge to be happy despite everything. There is always plenty to complain about but it actually requires an effort to focus on good things.

Why is the discussion about happiness taken for granted? In Kadish's exploration of this question, Tracy is thinking of writing a book about happiness: "I'm saving this, of course, for my post-tenure book. I'm not naïve. Talking about happiness is career suicide. I'll be accused of championing pap - of responding to a book not as a critic, whose role is to dissect, but from my kishkas" (Kadish 5). Why do academic novels not show us as shiny happy people? Why is it suspect to be happy in academe? Perhaps it is because "serious" academics believe happiness interferes with objectivity. Perhaps because emotions are not encouraged in a research environment. But where does the stigma come from? I love laughing while teaching and I derive profound pleasure whenever I can make my students smile and laugh. Yes, we tackle serious matters but there is room for jokes.

Teaching and research are Tracy's reason for living. I identify with her, it is a very strong drive in my life as well, verging on workaholism. Life is work, work is life. Until she meets George, she is safely ensconced in the ivory tower. When asked by George about her life, she talks about her work first and foremost:

I love books . . . I love the escape. Academics aren't supposed to say that, but it's true. I love to dive into somebody else's vision, nightmare, utopia, whatever. I love how books put a dent in our egos - turns out we're not the first sentient generation on the planet after all. Other people have been just as perceptive, just as worked up, about the same damn human problems we face. (Kadish 42)

Suddenly her neatly organized world of scholarship and occasional friendships turns upside down: she becomes engaged, breaks off the engagement, has draining problems with a sick, and therefore cantankerous, colleague, and with a graduate student she advises. She is skeptical about marrying George, and initially scholarship is a more reliable source of happiness than people. However, she will soon learn first-hand that academia is not the last bastion where if you do your job, 
and do it well, you will be shielded from all manner of human-inflicted calamities.

Knowledge of her planned research leaks within the department and since her tenure review is coming up, this is another stress-inducing factor. She realizes this could be her demise, because

I think there's a deep, long-running bias against literature about happiness. A cultural mistrust of anything but tragedy ... It's as if our whole literary tradition, which has been unsparing on the subjects of death, war, poverty, et cetera, has agreed to keep the gloves on where happiness is concerned . . . Anybody who tries to take happiness seriously is belittled . . . There's this cultural fear of thinking seriously about happiness. (Kadish 159-160)

Looking around, I see more unhappy literary academics than happy ones. Some people, it seems, would rather wallow in unhappiness than take things in stride and start acting with agency, like a homo faber.

Although in love, the idyllic state does not last forever for Tracy. When it rains, it pours: she parts with George, the colleague harasses her in many new ways, she is denied tenure, and the student attempts suicide. Tracy tries to fight for George, but because of his silent and stubborn resistance, she finally gives up. She helps the student, although it is not her responsibility. In her most desperate moments, she wants to escape into books:

I think of reading Tolstoy at two o'clock in the morning, my mind hopping so it's nearly intolerable to sit at my computer. Of burying my own confusion in Hurston's tongue-in-cheek prose. The lure, the warming light, of books. How delicious it might feel to follow that beacon, farther and farther from shore, until there remained no hope or desire to return. (Kadish 233)

But escaping will not solve her problems. Change is inevitable and she realizes she will have to edit her life and priorities. When she leaves the building after a very painful and unjust tenure denial, she sees George waiting for her. So there is a happy ending to her story and she relaxes into her life, thinking "Let me go through life the way we are, after all is said and done, meant to: shocked" (Kadish 325). It is a shocking realization that people in academia, her colleagues, nearly break her 
wonderful spirit. What saves her ultimately is friends and love. Her happiness is contingent on change, which is not an easy feat; it entails difficult emotions and decisions of letting go. There is nothing banal about her story, even if she chooses personal happiness instead of academe. Yes, Tracy achieves happiness, but the suggestion that one must choose between happiness and success in academia is not the sort of affirmation I sought, an affirmation that academic life will assure my happiness.

The Rosie Project by Graeme Simsion proves that even if one defines oneself mainly in terms of one's occupation as a science professor, one will not be happy. Humans and emotions are the only keys to happiness. Professor Don Tillman is a geneticist in his prime looking for a wife, but he has a version of Asperger's that does not lead to second dates. His family ties are strained as well: "My father and I have an effective but not emotional relationship. This is satisfactory to both of us. My mother is very caring but I find her stifling. My brother does not like me ... I do not see my family very often. My mother calls me on Sundays" (Simsion 207).

He plans to find a wife by using the only methods he is familiar and comfortable with, namely scientific ones: "I may have found a solution to the Wife Problem" (Simsion 1), he says matter-of-factly. He devises a questionnaire and begins dating. But the candidates are never perfect. His days are planned to the minute, his research impeccable, and his life devoid of emotions and surprises. He does not make friends easily and so far it seems he only had four of them: his sister who passed away due to medical incompetence, Daphne, an elderly neighbor he spent time with until she developed Alzheimer's and had to be placed in a home, and currently Gene and Claudia, Tillman's ties to the real world. Enter Rosie, a disorganized Ph.D. student in psychology, working as a bartender, who would like to learn who her biological father is. Don becomes passionate about the project and in a series of comic events they collect and test the DNA of forty plus possible candidates who might have impregnated her mother years ago at the graduation party.

It takes longer for Don than it would for most people (including the readers), to realize he loves Rosie. Before he wins the girl (she is in love with him, too, but apprehensive of his emotional shortcomings), he 
teaches himself the art of bartending and dancing. The blossoming emotions he experiences are a surprise to him and he realizes he will have to make an effort and change his lifestyle in order to accommodate love. He will have to compromise in order to keep academia and Rosie in his life.

Rosie teaches him spontaneity, something he usually sees as a threat to his ordered academe-oriented existence (and perhaps a suspect quality for many in academic life) and especially the field he is steeped in, genetics. The two of them share spontaneous joys such as enjoying a meal on the balcony inconsistent with his scheduled menu, an unplanned trip to a movie theatre, a visit to New York with everything it has to offer. She appreciates his efforts to help identify her father and they find they enjoy each other's company. He is a nerd but he is also attractive to Rosie, who sees in him a modern version of that old-school ideal man: Atticus Finch from To Kill a Mockingbird.

With the help of his friends and their expertise in relationships, he is able to work things out with Rosie, a work-life balance is won and preserved. The novel is funny and positive, due to Don's idiosyncratic use of the English language and comic situations arising from his inability to empathize but also due to its happy ending. The Rosie Project suggests that happiness derives from two people making an effort to work, live together, and share responsibilities, rather than from career or setting. The happiness is in them, not outside. The novel made me feel good about life in general and academic life in particular. It corroborated my feeling that happiness is a state of mind, not a state of things. Living consists of being happy and feeling down. Happiness is a thing apart from academia, coming from other sources, human interactions mainly. Academic life can only be an accessory to happiness, not its sole source.

Save Your Own by Elisabeth Brink is one of the most inspiring academic novels I have read so far. It narrates the story of Gillian Cormier-Brandenburg, a graduate student in her fourth year at Harvard Divinity School, also a twenty-five-year-old virgin, and a highly selfreflective individual with numerous insecurities. She is hard at work trying to discover a secular religion which "would render wars, slaughter, and tribal prejudices completely unnecessary. It would save us before we 
killed each other off" (Brink 6). Even though he has to tell her that her funding has been cut, the Dean is impressed with Gillian's enthusiasm: "That's one heck of a leap. But I have to give you credit. In all my years of teaching, you're the first graduate student I've had who thought a dissertation could change the world, much less save it. You're not afraid of big ideas. I like that in a scholar" (Brink 6). Yes, Gillian is one of those who think their work can fix the world's problems. I, too, had similar moments when I hoped that I could enact change as a scholar.

When her fellowship is revoked, Gillian, a bookish girl with poor social skills, plagued with self-doubt and self-hatred, accepts the challenge of working in a halfway house, supervising and counseling its residents. She finds human interaction anxiety-provoking at first, essential later. She makes friends, possibly for the first time in her life, and falls in love, also a first for her, since it is reciprocated. Many new situations and confrontations at the halfway house make her want to quit, induce narcolepsy, lead her to chant encouraging words and sentences, make her faint, but she brings to the job honesty, hard work, and organizational skills. Of course these are strengths that should also produce success in the academy - though in Gillian's case they did not. In this house she is mocked but also accepted. The women there have more sympathy and tolerance than she has been used to encounter in the ruthless world outside, especially the Ivy League graduate school. In a moment of honesty shared with a resident of the halfway house, Gillian intimates what it is like to be in graduate school:

I began by describing the horrible boiling cauldron that is Harvard Divinity School. The immense pressure, the cutthroat competition, the rigorous performance standards, the knifelike bias against short ugly people with squeaky voices. I touched upon the poverty, the isolation, the months and years of tedium. (Brink 133)

Once she stops fixating on her graduate career, leaves the ivory tower, and starts interacting with non-academics, Gillian starts having needs other than research and for example paints her room in order to feel better. Her mother asks "Do you really have time for a project like that?" Her father sermonizes "Writing a dissertation requires unwavering focus, 
Gillian, the handful of graduate students who go on to achieve renown are the ones who can push distractions aside" (Brink 144).

There are very high expectations to be met when studying at Harvard but Gillian realizes it is not an auspicious environment for her individually. Yet it takes courage to leave without feeling that one has failed. Reading this novel and corresponding with its author in one of my bleakest moments while at graduate school, has helped me persevere when, according to logic, I should have quit. Paradoxically, Gillian's courage to quit strengthened my determination to continue. I am deeply grateful for that experience which could have broken me, but made me instead.

Gillian's parents, both academics and scientists, are inconsolable when they learn she has gone astray from the academic path. She continues working at the house and possibly making her first independent decision, she cuts the cord, realizing she has her own life to live. Gillian learns to appreciate the company of other people, not necessarily scholars, and begins to enjoy that as opposed to the isolation she suffered so far.

Whenever she stops fixating on herself, and reaches out to others, she feels fine. She reinvents her life according to her own rules, not her parents' academic expectations anymore. She works full-time at the halfway house, writes a book called The Courage to Change and years later returns to graduate school, in Harvard's Department of Psychology where she writes a dissertation about personal change. She starts teaching, receives tenure, and establishes Icarus: A Foundation for Interdisciplinary Study in the Humanities which supports "scholars with nontraditional approaches to age-old questions and sometimes publish groundbreaking books that have been turned down by the usual array of presses" (Brink 279). Then she adopts a Chinese girl from an orphanage and raises her the best she can. In the evenings Gillian retires to her pale blue room to "take a few moments, as [she does] every night, to go to [her] window, gaze at the stars, and marvel at the practical causes and mysterious forces that make us who we are" (Brink 281).

Kindness, gratitude, and human interaction form the fundamentals of happiness, according to Elisabeth Brink in this refreshing, optimistic but in no way simplistic, or happy-go-lucky, campus novel. This is by far 
the most analytical, yet inspirational graduate-student-oriented novel I have ever read. She finds happiness in herself, in her interactions with people, and then resumes her academic career. Her temporary unhappiness teaches me that being dishonest with myself, acting in order to make others happy while being in denial about what makes me happy, is a straight path to burnout and depression. Gillian should have been in Psychology, rather than Divinity, but she needed to learn her lessons. So shortcuts could have gotten her where she needed to be, but her indirect process leads to a more profound happiness.

\section{Conclusion}

Why should we read campus novels? Why do I read campus novels? Because some of them elicit harmless laughter, and some inspire change of the unbearable situations one sometimes finds oneself in. Elisabeth Brink's novel makes one realize that the only way to function successfully in academe is to balance that unhealthy self-fixation we adopt when we isolate ourselves to do research with human interaction. We must interact with others, be they friends and family, students, or colleagues.

Re-orienting oneself towards others is one thing that helps in pursuing happiness. But how to alleviate the work-induced stress and frustration? One lesson a reader can learn from reading academic novels is that our possibilities of happiness depend on balancing the work with life and activities outside of academe. I believe that doing something entirely different, for example biking, can be key to preserving one's sanity. It is active, rather than passive; physical rather than contemplative; outdoors rather than indoors, and thus a relief from too much life of the mind. Two of the novels I discuss here offer biking as a release. Bikes and motorcycles occur as vehicles which offer a modicum of unrestrained freedom, therefore signaling happiness. When driving fast with Rosie, Prof. Tillman reflects on and marvels at his own sudden and brand-new happiness experienced regardless of academic life:

Hurtling back to town, in a red Porsche driven by a beautiful woman, with the song playing, I had the sense of standing on the brink of another world. I recognized the feeling, which, if anything, became stronger as the rain 
started falling and the convertible roof malfunctioned so we were unable to raise it. It was the same feeling that I had experienced looking over the city after the Balcony Meal, and again after Rosie had written down her phone number. Another world, another life, proximate but inaccessible. (Simsion 108)

Similarly, Gillian discovers the joys of life previously unavailable to her, for example riding a motorcycle with Janet from the halfway house. The motorbike ride causes ecstasy and is a moment reminiscent of Tillman riding with Rosie:

The wind on my body was an intoxicating mix of soft invigoration - part slap and part caress. I felt wild and little woolly. I had to smile. I couldn't believe myself. Not three hours ago I had been dressed down by the dean of the Divinity School of Harvard University and had throbbed with selfloathing, believing that my career was over, and now here I was on the back of a speeding motorcycle, my arms stretched out like wings, gulping mouthfuls of wind. Why should I care about deadlines and dissertations? Why should I care about anything when I could feel like this? My smile spread from ear to ear, and I began to laugh. Life is good, I thought, chortling. (Brink 76)

Fast bike and motorcycle rides can trigger highs, even in academics, releasing endorphins seldom associated with reading and research, but no amount of them will help if one succumbs to workaholism. It is not the answer, life is. Neither is lack of change, when the situation proves stifling. These books showed me that academic life can be happy and the other academic novels that I continue to read reinforce the view they provide that it is not if I do not have it in me to be happy. No one and no one thing is responsible for my own happiness. Neither academic life, nor any other professional life for that matter, is an automatic source of incessant satisfaction. The only solution is striking a happy medium, finding the work-life balance, with enough friendships and romance to offer support when life is not what we want it to be. I would recommend these novels to those who think academe spells unhappiness or happiness. It does neither. On that note, I will go and ride my bike now. No more reading tonight. 


\section{Works Cited}

Brink, Elisabeth. Save Your Own. New York: Houghton Mifflin Company, 2006. Print.

Kadish, Rachel. Tolstoy Lied: A Love Story.Boston, New York: Houghton Mifflin Company, 2007. Print.

Moseley, Merritt. "Introductory: Definitions and Justifications." The Academic Novel: New and Classic Essays. Ed. by Merritt Moseley. Chester: Chester Academic Press, 2007. 3-19. Print.

Rossen, Janice. The University in Modern Fiction: When Power Is Academic. New York: St. Martin's Press, 1993. Print.

Simsion, Graeme. The Rosie Project. London: Penguin Books, 2014. Print. 